usual. Particular interest will perhaps be found in the individual reports of the several institutes and bureaux, where abundant illustration is afforded of the value now attached to them by the number and diversity of the inquiries sent from all parts of the Empire, quite apart from their regular work of preparing and distributing abstract journals. Research workers in South Africa, Queensland, Sierra Leone, Cyprus, Mauritius, Victoria, India, northern England and the Gold Coast have asked for and obtained assistance from the Mycological Institute in the identification of fungi. At the Entomological Institute, insects from every country in the Empire have been received for identification. Other bureaux have assisted in obtaining material for plant breeding work, in supplying seeds, in arranging for the analysis of foodstuffs ; whilst the laboratory attached to the Imperial Institute of Entomology collected and sent to Canada nearly three million parasites to aid in controlling the insect pests which were attacking the forests in Quebec and the Maritime Provinces. In fact, the report marks for the seventh year the success of an Imperial service, organized on a cooperative basis and directly controlled by representatives of all parts of the Commonwealth.

\section{Rock Gardening}

THE art of growing plants among rocks disposed artistically is, perhaps, the highest form of gardening. It calls forth skill of an exceptional order, and provides a medium for expression of the highest sense of art. The Royal Horticultural Society and the Alpine Garden Society are therefore to be congratulated upon their very successful joint organization of a conference on rock garden matters, and an exhibition of tasteful grouping of alpine plants. The deliberations of this Conference, which took place at the Greycoat Street Hall on May 5-7, 1936, have now been published in book form by the Royal Horticultural Society ("Rock Gardens and Rock Plants." London: from the Office of the Society, Vincent Square, S.W.1, pp. 171, 6s. net, 1936). Mr. F. J. Chittenden has edited this report of proceedings. Practical considerations were well to the fore. The utilization of natural slopes and of flat sites, the cultivation of difficult alpine plants, methods of propagation, the use of an alpine house, and other problems, were discussed. The history of rock gardens was outlined, and a very pleasing international atmosphere was introduced by the speakers who described rock gardening in South Africa (Miss Stanford), in Quebec (Mr. Cleveland Morgan) and in Southern California (Mr. W. Hertrich). The impression gained from the volume is that the artistic side of rock gardening could scarcely be improved, and that present-day practice is enlightened and highly skilled. There are abundant indications, however, in the papers and in the energetic and constructive discussion which followed them, that there is a field where a sympathetic man of science, working upon rock-garden problems, might furnish great contributions to practice, and satisfy many botanical questions which must at present be left unanswered.

\section{Forestry in British Honduras}

THE report of the Forest Trust of British Honduras to the end of December 1934 (Belsize : Govt. Printer, 1935) shows some progress in forestry work after the severe experiences following the 1931 financial crisis. From the Colonial Development Fund grants were made towards forest development in the Colony. The chief of these grants was to provide the staff to undertake a forest resources survey of the country, provided that the local Government contributed towards the cost and that the officer seconded for the work was replaced on the executive staff by an additional officer. The step so taken furnishes evidence of a broad vision on the part of the officials forming the Forest Trust. The term 'research work' accorded to what is mainly ordinary stock mapping of a forestthe work, or part of it, of the trained forest officer-is rather out of place, if not misleading. The staff of the Department, consisting of three gazetted officers, is still too small to make any considerable advance in executive forestry work a possibility. It is not therefore surprising to find in the Report such remarks as "No new reserves have been created"; "No new demarcation work was undertaken"; and, in spite of the magnificent start made in the early years of this young Department, that "No sylvicultural work has been done since the completion of the mahogany improvements in 1931". The end of the year 1934, which appears very distant at the present day, seemed to show an upward tendency in a timber trade revival. It was estimated by the Trust that the export of mahogany, that magnificent forest product of the British Honduras forests, would not exceed five or six million board feet per annum in the immediate future, and that a large proportion of that export would be in lumber form.

\section{Exhibition of Microscopes}

Messrs. W. Watson and Sons, Litd., heid their fourth exhibition of microscopes at the Central Hall, Westminster, on December 7-11, when the manifold uses of the microscope were practically illustrated, and many different types of instrument were on view. Members of the Quekett Microscopical Club were helpful in explaining points of interest to the scientific microscopist and instilling enthusiasm for microscopy in the amateur. A large number of different microscopes, from the comparatively simple student's microscope to the more intricate type used for research purposes, was on view. Other apparatus being demonstrated included photomicrographic and other cameras, dyes and stains, dissecting instruments, micro-projectors, telescopes, and other optical instruments. Messrs. Chance Bros. supplied an exhibition of glass in various stages from the rough mass to the finished optical lens. Messrs. Kodak also had an exhibition, as also had Polarisers, Ltd. A catalogue of the exhibition forms a useful guide to scientific workers in the many branches of science in which the microscope is indispensable and also to the amateur microscopist. The catalogue can be obtained from Messrs. W. Watson and Sons, Ltd., 313 High Holborn, London, W.C.1. 